\title{
PARACETAMOL INDUCED ANGIOEDEMA: MORE DETAILS REQUIRED
}

Sir,

I have read with keen interest the case report of a 4-year old boy who supposedly developed angioedema due to paracetamol. ${ }^{[1]}$ The authors have attempted to justify with reasons that the angioedema was most likely due to paracetamol. The patient was treated for presumed viral infection; yet, the viral infection was not considered a possible cause of the angioedema. The fact that the reaction occurred within an hour of receiving the first dose of paracetamol and that it happened on just a single occasion made the reaction acute angioedema. ${ }^{[2]}$ The commonest cause for a single isolated attack of angioedema is probably viral infection. Viruses are usually blamed because immune response to environmental 
microbes may take an odd course to produce angioedema. This explanation is thought to be likely when this kind of reaction occurs in children. ${ }^{[2]}$

A good past medical and drug history is a cornerstone to preventing and managing adverse drug reactions. ${ }^{[3]}$ Unfortunately, it was not properly explored in the patient. A previous report of hypersensitivity to paracetamol has shown a high incidence in children with personal/familial history of atopy or previous reaction to non-steroidal anti-inflammatory drugs (NSAIDs), acetylsalicylic acid (ASA) and antimicrobials. ${ }^{[4]}$ One wonders if this was the first episode of fever in this patient's lifetime. If not, how were they treated? Previous fever episodes were likely to have been treated with paracetamol or NSAIDs. Self-medication is a recognized problem in India ${ }^{[5]}$ and other developing countries. ${ }^{[6]}$ Paracetamol remained one of the most commonly self-medicated medicines for children and the medicine mostly kept at home by parents, ${ }^{[6]}$ therefore the likelihood of use of paracetamol or other medicines with potential for hypersensitivity reactions is high in the patient reported. The previous use of paracetamol, NSAIDs, ASA or antimicrobials might have sensitized the patient to produce the reported angioedema in a manner similar to type I allergic reaction or an aberrant non-allergic reaction, otherwise called idiosyncratic reaction. ${ }^{[7]}$ The only way to establish paracetamol hypersensitivity in this patient is to take a good clinical history or do oral challenge tests for NSAIDs, ASA and paracetamol when clinically stable. ${ }^{[3]}$ Unfortunately these were not done. The oral challenge tests should be performed in the hospital, under strict supervision.
The formulation and source of the paracetamol is equally important in this case. The shelf life and stability of medicines kept at home, especially on a warm climate, are known to decrease over time, thereby increasing loss of potency and possible toxicity. ${ }^{[6]}$ The use of contaminated and adulterated paracetamol for children was responsible for multiple adverse reactions culminating in deaths in Nigerian children. ${ }^{[8]}$

Overall, the case report was interesting but left so many questions unanswered. Publication of case reports describing suspected adverse reactions to drugs and medical products should provide sufficient details for either a differential diagnosis or provisional assessment of cause-effect association, or a reasonable pharmacological or biological explanation for the reaction.

KAZEEM A OSHIKOYA

Department of Pharmacology and Paediatrics, Lagos State University College Medicine, Ikeja, Lagos, Nigeria

\section{Correspondence:}

Dr Kazeem A Oshikoya, Academic Division of Child Health, University of Nottingham, The Medical School, Derbyshire Children's Hospital, Uttoxeter Road, Derby DE22 3DT, United Kingdom. E-mail: med_modhospital@yahoo.com DOI: $10.4103 / 0019-5359.48557$

\section{REFERENCES}

1. Panchabhai TS, Gogtay NJ, Bavdekar SB. Paracetamol induced angioedema. Indian J Med Sci 2008;62:420-2.

2. Brostoff J, Radcliffe M. Urticaria and angioedema. Available from: http://www.allergyclinic.co.uk/ angioedema.htm, [Cited in Dec. 2008].

3. Oshikoya KA, Njokanma OF. Adverse drug reactions in children: A review of management. Int J Pharmacol 2007;3:11-8.

4. Boussetta K, Ponvert C, Karila C, Le Bourgeois M, 
de Blic J, Scheinmann P. Hypersensitivity reactions to paracetamol in children: A study of 23 cases. Allergy 2005;60:1174-7.

5. Sharma R, Verma U, Sharma CL, Kapoor B. Selfmedication among urban population of Jammu city. Indian J Pharmacol 2005;37:37-45.

6. Oshikoya KA, Njokanma OF, Bello JA, Ayorinde EO. Family self-medication for children in an urban area of Nigeria. Paediatr Perinat Drug Ther 2007;8:124-30.

7. Oshikoya KA. Adverse drug reactions in children: type, incidence and risk factors. Niger J Paediatr 2006;33:29-35.

8. Okuonghae $\mathrm{HO}$, Igbogboja IS, Lawson JO, Nwana EJ. Diethylene glycol poisoning in Nigerian children. Ann Trop Paediatr 1992;12:235-8. 